Bawden, F. C. \& Pirie, N. W. (1957). J. gen. Microbiol. 16, 696-710

\title{
A Virus-inactivating System from Tobacco Leaves
}

\author{
By F. C. BAWDEN ANd N. W. PIRIE \\ Rothamsted Experimental Station, Harpenden, Hertfordshire
}

\begin{abstract}
SUMMARY : Purified preparations of the Rothamsted tobacco necrosis virus made by sedimenting the virus from freshly expressed sap lose infectivity slowly at $0^{\circ}$ and rapidly at $18^{\circ}$. Stable infective preparations can be made by ultracentrifugation provided the sap is first frozen or allowed to age; unstable preparations can be stabilized by prolonged centrifugation at $8000 \mathrm{~g}$, or by incubation with citrate and azide. Stable virus preparations lose their infectivity when exposed to the material that sediments from leaf sap centrifuged at $4000-8000 \mathrm{~g}$. This inactivation demands air and is prevented by the presence of azide, but when the sedimented material is kept in air at $0^{\circ}$ for some hours a low-molecular weight substance separates from it, and this inactivates the virus whether or not air or azide are present. The material sedimented from the sap of uninfected tobacco leaves, or leaves infected with tobacco mosaic virus, inactivates virus less readily than does material from leaves infected with tobacco necrosis or tobacco ringspot virus. The sediments inactivate tobacco ringspot but not tobacco mosaic virus. The nature of the inactivating substance made by the sediments is unknown, but aldehydes and derivatives of ascorbic acid have comparable effects. Inactivated virus preparations are still serologically active and resemble active ones in all other properties studied.
\end{abstract}

The ratio of infectivity to the amount of specific antigen contained in purified preparations of the Rothamsted culture of tobacco necrosis virus (RTNV) varies with different preparations and depends on the treatments that are applied to infected leaves or to extracts from them. Although we (Bawden \& Pirie, 1950a) remarked of these phenomena that 'few are definitely interpretable and many are not consistently reproducible', at that time there did seem substantial evidence that virus particles could lack infectivity when first released from infected leaves and acquire this property in vitro. A main reason for this conclusion was that virus preparations made by ultracentrifuging freshly expressed sap at $0^{\circ}$, conditions we thought most likely to yicld and maintain the virus in its initial state, were less infective than preparations made by rougher methods or by sedimenting the virus after the sap had stood for some time, and this despite the presence in sap of low molecular weight components that can destroy infectivity (Bawden \& Pirie, 1950 $a, b$ ).

Later work made this conclusion increasingly improbable and we have already disclaimed it (Pirie, 1953; Bawden \& Pirie, 1956). Our first approach to studying these variations was to compare the infectivities of leaf extracts made in different ways and exposed to different conditions. Studies with more than 100 separate batches of leaves have made results more systematic, but the systems involved are too complex and the effects often too small to be interpreted confidently. These studies showed the fallacy of our assumption that the virus would remain most nearly in its original state when sedimented from the environment of sap as quickly as possible. They showed that partially 
purified preparations of RTNV lose infectivity when exposed to conditions that have little or no effect on the infectivity of highly purified preparations or of infective sap. This suggested a direct approach by looking for inactivating systems in the partially purified preparations. Our latest results suggest that, in freshly expressed sap, there is a system which sediments along with the virus and produces substances that destroy infectivity. Ultracentrifugation therefore concentrates both the virus and the inactivating system, and creates conditions in which infectivity is soon affected even at $0^{\circ}$. Either the system itself, or its association with sedimentable particles, is unstable in the conditions obtaining in sap, and when ultracentrifugation is increasingly delayed less of the inactivating system appears in the final virus preparations, which are correspondingly more stable.

This interpretation seems to be confirmed by the fact that we can now make relatively stable preparations of RTNV and then remove their infectivity by exposing them to other preparations made by methods designed to preserve the inactivating system. Work with mixtures of stable, highly purified RTNV and concentrated preparations of the inactivating systems gives unequivocal results, and for the sake of clarity we shall illustrate the phenomenon by describing experiments with such mixtures.

The inactivating system is not specific to tobacco leaves infected with RTNV, and its inactivating action is not confined to RTNV, though it does not extend to all plant viruses. We do not know whether the system has any significance in vivo, and for this reason we have not continued our work to the point of identifying the substances that destroy infectivity. Although the system is of questionable biological importance, it is important because of the extent to which ultracentrifugation is now used to make virus preparations, and we publish our results partly to show that misleading results may come from this technique.

\section{METHODS}

The virus culture was derived by continuous propagation of the one used earlier, and we have no evidence that it has changed in any way that affects our results. It still produces only necrotic local lesions in the three species of plants we infect, tobacco (Nicotiana tabacum, var. White Burley), N. glutinosa and French bean (Phaseolus vulgaris, var. Prince). Purified preparations still contain specific particles of more than one size, and the pellets sedimented from them by ultracentrifugation still have the characteristic crystalline structure (Bawden \& Pirie, 1945). Most of our experiments were made on extracts from infected tobacco leaves, which were treated and inoculated as already described (Bawden \& Pirie, 1945, 1950a). Inoculum for the batches of tobacco leaves usually came from $N$. glutinosa to decrease the risk of contamination with tobacco mosaic virus. Infectivity assays were made in French bean; these, and precipitation tests with RTNV antisera, were again made by methods already described. Tobacco ringspot virus was propagated in tobacco, and its infectivity was also assayed by counting local lesions produced in tobacco.

Preparation of the virus-inactivating system. Tobacco leaves were picked 
when well covered with lesions but before they were wholly shrivelled, usually about a week after inoculation, but the actual time varied between 6 and 12 days depending on the temperature, the infectivity of the inoculum and the susceptibility of the batch of plants. The mid-ribs were cut out, the laminae minced in a chilled mincer, and the sap pressed from the mince by hand through fine cloth into a jar surrounded by ice. The sap was immediately centrifuged for $5 \mathrm{~min}$. at $7000 \mathrm{rev} . / \mathrm{min}$. $(4000 \mathrm{~g})$ and the supernatant fluid centrifuged again for $20 \mathrm{~min}$. at $10,000 \mathrm{rev} . / \mathrm{min}$. $(8000 \mathrm{~g})$. Both centrifugations were done in a cold room and the preparations were kept always near $0^{\circ}$ because the system is soon destroyed at higher temperatures. The first sediment, which consists mainly of starch, chloroplasts and their fragments, and pieces of cell wall, was discarded, and the second supernatant fluid was kept as the source of virus. The second sediment, which contains the bulk of the virus-inactivating system, was suspended in a volume of water equal to one-fifth the volume of the original sap and immediately centrifuged again at $10,000 \mathrm{rev} . / \mathrm{min}$. The second sediment was again suspended in water and its dry matter determined by drying a sample in vacuo and weighing.

Preparations made in this way are dark green and contain 0.6-1.0\% $\mathbf{P}$, which is mainly in the form of a nucleoprotein that hydrolyses when incubated at $18^{\circ}$ for a few hours with salts, especially citrates (Pirie, 1950). For convenience we shall call them preparations of mitochondria, but no anatomical or chemical significance should be attached to the name. Other preparations, differing from the mitochondria in appearance and constitution and, weight for weight, about one-quarter as active in destroying the infectivity of RTNV, can be made by more prolonged centrifugation of the second supernatant fluid at $10,000 \mathrm{rev} . / \mathrm{min}$. The resulting sediment contains from $1-2 \% \mathrm{P}$ and little or no chlorophyll, so there is no reason to relate the system that inactivates RTNV with either the nucleoprotein or the chromoprotein present in the more active preparations.

Preparations of stable infective virus. The simplest way to get stable highly infective preparations of RTNV is to keep the supernatant fluid from the $10,000 \mathrm{rev} . / \mathrm{min}$. centrifugation for a day or two at room temperature, because the virus-inactivating system is then rendered ineffective and much of the normal protein denatures. Most of our preparations were made after this preliminary treatment. The stored sap was clarified by centrifugation at $7000 \mathrm{rev} . / \mathrm{min}$. and the virus was then either sedimented by centrifugation at $40,000 \mathrm{rev} . / \mathrm{min}$. $(80,000 \mathrm{~g})$ or concentrated by freezing-out most of the water. The purification was completed by methods already described (Bawden \& Pirie, $1950 a$ ). We sometimes used another method that gave preparations of comparable stability and infectivity. The supernatant fluid from the $10,000 \mathrm{rev} . / \mathrm{min}$. centrifugation was centrifuged at $40,000 \mathrm{rev} . / \mathrm{min}$. while fresh and the bulky sediment resuspended in water and immediately incubated with $\mathrm{M} / 20(\mathrm{pH} 6)$ sodium citrate and $\mathbf{2}$ g./l. neutral sodium azide. This incubation destroys contaminating nucleoprotein and the virus-inactivating system without much affecting the infectivity, and after clarifying the incubated solutions, the virus can be further purified. 
Tests for inactivation. For tests of their ability to inactivate RTNV, preparations of the sediments obtained at $10,000 \mathrm{rev} . / \mathrm{min}$. are conveniently used at about $10 \mathrm{~g} . / 1$. At this concentration they remain active for a few days at $0^{\circ}$ and a month or so at $-20^{\circ}$. Preparations retain their activity at $0^{\circ}$ for longer when they contain $2 \mathrm{~g}$. sodium azide/l. Before they were used in experiments, preparations stored with azide were diluted with 50-100 times their volume of water and sedimented at $10,000 \mathrm{rev} . / \mathrm{min}$. Inactivation tests were usually made with mixtures containing $10 \mathrm{~g} . / 1$. of the inactivating system and from $0 \cdot 2$ to $1.0 \mathrm{~g}$. purified virus/1.; the amount of virus was varied according to the infectivity of the preparation and the susceptibility of the test plants. The ratio of 10 or more parts of the mitochondrial preparation to one of virus is greater than would normally occur during the processes of virus purification and was used to ensure clear-cut results. At the end of the incubation period, the mixtures were diluted 1/100 with water, which stops any further inactivation of the virus, and were then inoculated to bean plants at this dilution and at a further dilution of 1/10. No buffer was added, but the $\mathrm{pH}$ value of mixtures that inactivated was often measured and was always between $\mathbf{5 \cdot 5}$ and 6.5 ; the virus is stable over a wider range than this.

\section{RESULTS}

\section{Properties of the inactivating system}

Freshly made preparations of the inactivating system contain some infective virus, which is tenaciously held through repeated sedimentations in the cold, but infectivity is soon lost at $18^{\circ}$. In the experiment recorded in Table 1 a sample of a $10 \mathrm{~g}$./1. preparation made within $2 \mathrm{hr}$. of harvesting infected

\section{Table 1. The effect of washing and of incubation on the infectivity of a mitochondrial preparation}

Part of a $10 \mathrm{~g} . / 1$. mitochondrial preparation from leaves infected with R'TNV was incubated at $18^{\circ}$. Another part was diluted to $0 \cdot 1 \mathrm{~g} . / 1$, a sample stored at $0^{\circ}$, and the remainder centrifuged at $10,000 \mathrm{rev} . / \mathrm{min}$. The sediment was resuspended at $10 \mathrm{~g} . / 1$. , sampled and treated like the original preparation. The second sediment was also resuspended at $10 \mathrm{~g}$. $/$. and incubated at $18^{\circ}$, and a sample at $0.1 \mathrm{~g} . / \mathrm{l}$. was stored at $0^{\circ}$. Inoculations were made $20 \mathrm{hr}$. later with all samples at $0 \cdot 1 \mathrm{~g} . / \mathrm{l}$. and the results are given as the numbers of lesions produced on six half leaves.

\begin{tabular}{llr}
\multicolumn{1}{c}{ Preparation } & \multicolumn{1}{c}{ Storage } & Infectivity \\
Original & $20 \mathrm{hr}$. diluted, at $0^{\circ}$ & 78 \\
& $20 \mathrm{hr}$. undiluted, at $18^{\circ}$ & 0 \\
Sedimented once & $20 \mathrm{hr}$. diluted, at $0^{\circ}$ & 54 \\
& $20 \mathrm{hr}$. undiluted, at $18^{\circ}$ & 0 \\
Sedimented twice & $20 \mathrm{hr}$. diluted, at $0^{\circ}$ & 47 \\
& $20 \mathrm{hr}$. undiluted, at $18^{\circ}$ & 0
\end{tabular}

leaves was incubated at $18^{\circ}$, the rest was diluted $1 / 100$ and most was centrifuged at $10,000 \mathrm{rev} . / \mathrm{min}$. while a part was stored at $0^{\circ}$. The sediment was suspended and re-sedimented twice. This repeated washing neither removed 
the virus from the sediment nor destroyed the ability of the sediment, when incubated at $18^{\circ}$, to inactivate the virus it contained.

Table 2 shows the rate at which fresh preparations lose their infectivity when kept at $18^{\circ}$ and that the loss is prevented or decreased when air is excluded or when the preparations contain sodium azide. Incubation at $18^{\circ}$ alters the material so that, instead of sedimenting only when centrifuged at 7000-10,000 rev./min., it flocculates. This flocculation is also partially prevented by azide.

\section{Table 2. The infectivity of mitochondrial preparations after exposure to various conditions}

One-tenth $\mathrm{ml}$. lots of a $10 \mathrm{~g} . / 1$. suspension of mitochondria from infected leaves were kept as specified and then diluted to $1 / 100$ and $1 / 1000$ before comparing their infectivities.

\begin{tabular}{|c|c|c|}
\hline \multirow[b]{2}{*}{ Exposure } & \multicolumn{2}{|c|}{$\begin{array}{l}\text { Nos. of lesions with } \\
\text { preparation diluted }\end{array}$} \\
\hline & $1 / 100$ & $1 / 1000$ \\
\hline $20 \mathrm{hr}$. at $0^{\circ}$, diluted $1 / 100$ & 84 & 35 \\
\hline $3 \mathrm{hr}$. at $18^{\circ}$, then diluted and $17 \mathrm{hr}$. at $0^{\circ}$ & 59 & 18 \\
\hline $10 \mathrm{hr}$. at $18^{\circ}$, then diluted and $10 \mathrm{hr}$. at $0^{\circ}$ & 3 & 1 \\
\hline $20 \mathrm{hr}$. at $18^{\circ}$, then diluted & $\mathbf{0}$ & 0 \\
\hline $20 \mathrm{hr}$. at $18^{\circ}$ in vacuo, then diluted & 43 & $\mathbf{2 4}$ \\
\hline $20 \mathrm{hr}$. at $18^{\circ}$ in $2 \mathrm{~g} . / 1$. sodium azide, then diluted & 80 & 31 \\
\hline
\end{tabular}

\section{Table 3. Inactivation of purified RTNV by various concentrations of two mitochondrial preparations}

One-hundredth ml. of $10 \mathrm{~g}$./l. purified RTNV was mixed with $0.09 \mathrm{ml}$. of mitochondrial preparations already diluted to give the stated concentrations. The mixtures were kept in air at $18^{\circ}$ for $20 \mathrm{hr}$. and then diluted $1 / 100$ and $1 / 1000$ before inoculation to bean leaves.

Condition of incubation
Virus alone
Virus with preparation $A$ at $1 \mathrm{~g} . / 1$.
Virus with preparation $A$ at $3 \mathrm{~g} . / 1$.
Virus with preparation A at $10 \mathrm{~g} / 1$.
Virus with preparation $B$ at $3 \mathrm{~g} . / 1$.
Virus with preparation B at $10 \mathrm{~g} . / 1$.

\begin{tabular}{|c|c|}
\hline \multicolumn{2}{|c|}{$\begin{array}{l}\text { Nos. of lesions with } \\
\text { virus diluted to }\end{array}$} \\
\hline $10 \mathrm{mg} . / 1$ & $1 \mathrm{mg} . / \mathrm{l}$. \\
\hline 420 & 235 \\
\hline 110 & 69 \\
\hline 39 & 20 \\
\hline 0 & 0 \\
\hline 280 & 111 \\
\hline 113 & 48 \\
\hline
\end{tabular}

Tests with artificial mixtures of purified virus and mitochondrial preparations were made in conditions where the purified virus contributed more than nine-tenths of the original infectivity, so that the fraction contributed by the mitochondria was too small to confuse the results even if it were more stable than indicated by the results in Tables 1 and 2 . Table 3 illustrates the differing abilities of mitochondrial preparations, from two different batches of leaves, to inactivate the same preparation of RTNV. Preparation A inactivated completely at $10 \mathrm{~g} . / \mathrm{l}$., and at $1 \mathrm{~g} . / \mathrm{l}$. inactivated as much as $\operatorname{did} \mathbf{B}$ at $10 \mathrm{~g}$./l. Preparation $A$ is by no means the most powerful inactivator we have made: some have diminished to one-third the infectivity of 10 times their 
weight of purified RTNV during $20 \mathrm{hr}$. at $18^{\circ}$. Differences of factors of three in infectivity between virus preparations were common during our work in 1950, and the partially purified virus preparations we were then making might well have contained more than one-tenth of their weight as mitochondrial contaminants. At the various stages when easily sedimentable material was separated from the virus, preparations were centrifuged only briefly at $7000 \mathrm{rev} . / \mathrm{min}$. The experiment set out in Table 4 shows that this was not enough to stabilize virus prepared by ultracentrifugation. The starting material for both preparations was fresh sap clarified by centrifugation for $5 \mathrm{~min}$. at $6000 \mathrm{rev} . / \mathrm{min}$., and the virus was sedimented twice. The final pellets were stirred with water to give approximately $2 \mathrm{~g} . / \mathrm{l}$. suspensions. Half of each suspension was then centrifuged for $5 \mathrm{~min}$. at $8000 \mathrm{rev} . / \mathrm{min}$., when the supernatant fluid was poured off; the other halves were centrifuged for $12 \mathrm{~min}$. at 10,000 rev./min. and the supernatant fluid carefully siphoned off without disturbing the sediment. The infectivity of both virus preparations, particularly at $18^{\circ}$, was stabilized by the greater centrifugation.

\section{Table 4. Increase in stability of RTNV brought about by centrifugation}

Preparation 1 was made from leaves five days after inoculation and preparation 2 four days later. Each preparation was centrifuged as specified and samples of the supernatant fluids were kept at $0^{\circ}$ and $18^{\circ}$ before diluting and comparing their infectivities.

\begin{tabular}{|c|c|c|c|c|c|}
\hline \multirow[b]{3}{*}{ Centrifugation } & \multirow[b]{3}{*}{ Storage } & \multicolumn{4}{|c|}{ Nos. of lesions } \\
\hline & & \multicolumn{2}{|c|}{ Preparation 1} & \multicolumn{2}{|c|}{ Preparation 2} \\
\hline & & $1 / 100$ & $1 / 1000$ & $1 / 100$ & $1 / 1000$ \\
\hline $5 \mathrm{~min}$. at $8,000 \mathrm{rev} . / \mathrm{min}$. & $\begin{array}{l}20 \mathrm{hr} \text {. at } 0^{\circ} \\
20 \mathrm{hr} \text {. at } 18^{\circ}\end{array}$ & $\begin{array}{r}182 \\
15\end{array}$ & $\begin{array}{r}25 \\
0\end{array}$ & $\begin{array}{r}221 \\
2\end{array}$ & $\begin{array}{r}37 \\
0\end{array}$ \\
\hline $12 \mathrm{~min}$. at $10,000 \mathrm{rev} . / \mathrm{min}$. & $\begin{array}{l}20 \mathrm{hr} \text {. at } 0^{\circ} \\
20 \mathrm{hr} \text {. at } 18^{\circ}\end{array}$ & $\begin{array}{r}190 \\
91\end{array}$ & $\begin{array}{l}30 \\
17\end{array}$ & $\begin{array}{l}410 \\
102\end{array}$ & $\begin{array}{l}57 \\
15\end{array}$ \\
\hline
\end{tabular}

Virus preparations that are more stable than any in Table 4 can be made by repeating the ultracentrifugation and prolonging the clarification at $10,000 \mathrm{rev} . / \mathrm{min}$., but it is easier to get stable preparations by methods already described for removing the inactivating system. When centrifugation alone is used, then the mitochondrial fraction needs to be removed by prolonged centrifugation at $10,000 \mathrm{rev} . / \mathrm{min}$. at each stage. It is not enough to do this treatment at the end of the ultracentrifugation cycle, unless this is done at $0^{\circ}$ and with the minimum of delay, because, as will be shown later, virusinactivating substances that are not sedimentable are produced as long as mitochondria are present.

Ultracentrifugation encourages the inactivation of $R T N V$ by increasing the concentration of both mitochondria and virus, for concentration is more important than the ratio between the two. A mixture of RTNV and mitochondria that loses all its infectivity in $20 \mathrm{hr}$. at $18^{\circ}$ when incubated at $5 \mathrm{~g} . / \mathrm{l}$., may lose only half or less when incubated at $1 \mathrm{~g}$./l. and suffer no detectable loss when incubated at $\mathbf{0} \cdot \mathbf{1} \mathrm{g} . / 1$. 
Table 5 compares the relative abilities of five different types of material from tobacco to inactivate RTNV. Three of these were made as already described for mitochondrial preparations, one from uninfected leaves, and two from infected plants, one with RTNV and the other with tobacco ringspot virus. The other two materials were both from leaves infected with RTNV; one was the sediment obtained by centrifuging sap at $7000 \mathrm{rev} . / \mathrm{min}$. and the other came from the leaf residue remaining after the leaves were minced and sap extracted. The residue was extracted with water in a high-speed blendor and then the extract was centrifuged at $10,000 \mathrm{rev} . / \mathrm{min}$. to obtain the sedimentable material. Mitochondrial preparations from plants infected with RTNV

\section{Table 5. The inactivation of $R T N V$ and tobacco ringspot virus by mitochondrial preparations from different sources}

One-tenth $\mathrm{ml}$. lots of water containing $1 \mathrm{mg}$. of the specified sediments and $20 \mu \mathrm{g}$. of purified RTNV were exposed to air at $18^{\circ}$ for $20 \mathrm{hr}$. Each was diluted to $4 \mathrm{ml}$. and tested at this and at a further dilution of 1/10. A partially purified preparation of tobacco ringspot virus was similarly incubated with only 2 of the sediments and diluted 1/100 before testing.

\begin{tabular}{|c|c|c|c|}
\hline \multirow[b]{3}{*}{ Virus incubated with } & \multicolumn{3}{|c|}{ Nos. of lesions with } \\
\hline & \multicolumn{2}{|c|}{ RTNV at } & \multirow{2}{*}{$\begin{array}{c}\text { Ringspot } \\
\text { virus at } \\
1 / 100\end{array}$} \\
\hline & $5 \mathrm{mg} . / \mathrm{l}$. & $0.5 \mathrm{mg} . / \mathrm{l}$. & \\
\hline Water & 475 & 365 & 250 \\
\hline $7000 \mathrm{rev} . / \mathrm{min}$. sediment from sap of leaves with RTNV & 35 & 8 & - \\
\hline $10,000 \mathrm{rev} . / \mathrm{min}$. sediment from sap of leaves with RTNV & 3 & o & 0 \\
\hline $\begin{array}{l}10,000 \mathrm{rev} . / \mathrm{min} \text {. sediment from blendor extract of leaf } \\
\text { residues }\end{array}$ & 360 & 111 & - \\
\hline $\begin{array}{l}10,000 \mathrm{rev} / \mathrm{min} \text {. sediment from sap of leaves with tobacco } \\
\text { ringspot virus }\end{array}$ & 10 & $\mathbf{0}$ & 0 \\
\hline $10,000 \mathrm{rev} . / \mathrm{min}$. sediment from sap of uninfected & 405 & 257 & - \\
\hline
\end{tabular}

and tobacco ringspot virus were equally active, but the other preparations were much less so. Table 5 also shows that the mitochondrial preparations from plants infected with $\mathrm{R}^{\prime} \mathrm{TNV}$ and tobacco ringspot virus inactivated tobacco ringspot virus as readily as RTNV. The activity of mitochondrial preparations from uninfected plants varied and some were more active than the one used for the experiment recorded in Table 5, but we have never made one that was as active as the least-active preparation from leaves infected with RTNV. Tobacco plants infected with tobacco mosaic virus give preparations no more active than those from uninfected plants. French bean leaves infected with RTNV also yield active preparations.

There is no evidence to show whether infection with RTNV or tobacco ringspot virus increases the amount of inactivator or makes it more readily sedimentable at $10,000 \mathrm{rev} . / \mathrm{min}$. Both these viruses cause necrotic lesions and the inactivator may increase in dying cells, but it also occurs in considerable amounts in leaves that are infected with tobacco ringspot virus and showing mainly chlorotic lesions.

Preparations from infected and uninfected leaves look alike and have 
similar compositions. A few measurements of their $\mathrm{O}_{2}$ uptake made in Warburg manometers, and of their catalase contents, suggest that infection enhances $\mathrm{O}_{2}$ uptake and diminishes catalase, but different batches of healthy leaves differ from one another so much that many more batches of plants would need to be studied before this could be stated confidently.

Some other variations in the preparative technique have had no consistent effect on the activity of the preparation. Thus tobacco leaves infected with RTNV were moistened with sucrose solution before they were minced so that the final extract contained $0.5 \mathrm{M}$ sucrose. 'This procedure stabilizes chloroplasts and other intracellular structures but, in many tests, has never affected the yield or the activity of the virus-inactivating system. Various other modifications to the method of extracting sap have also had little or no effect; these include pressing through a narrow slot (Pirie, 1956) and grinding in a mortar, either alone or with extracting fluids containing neutral ascorbate, cysteine, azide, cyanide, or buffers to raise the $\mathrm{pH}$ value to $7 \cdot 5$. By contrast with the lack of effect of these extracting methods, the subsequent treatment of extracts has a great effect. The technique we have described for making infective stable preparations of RTNV shows that freezing the sap and ageing it in vitro prevent inactivation. So also does shaking for 1-2 min. with chloroform, acidifying to $\mathrm{pH} 4 \cdot 8$, or dialysis. All these treatments greatly diminish the amount of material that sediments at $10,000 \mathrm{rev} . / \mathrm{min}$. from sap that has already been centrifuged at $7000 \mathrm{rev} . / \mathrm{min}$., but the small amount that does sediment is, weight for weight, less active than preparations as normally made. We have no evidence to show whether these treatments destroy the inactivating system, make it sedimentable at 7000 or unsedimentable at $10,000 \mathrm{rev} . / \mathrm{min}$. It is worth noting that Steere (1956) found shaking with $\mathrm{CHCl}_{3}$ a useful procedure in purifying tobacco ringspot virus, which is inactivated by the mitochondrial preparation.

Whether or not the inactivating system is destroyed rapidly in sap at $18^{\circ}$, there are still ample explanations for the greater stability of RTNV in sap than in partially purified preparations made by ultracentrifugation. First, the absolute concentration of the inactivator is much smaller and, secondly, sap contains substances that inhibit its action. The second is shown by the fact that mixtures of purified virus and mitochondrial preparations, which soon become non-infective when incubated alone, remain infective when incubated in the presence of either a filtrate from boiled sap or the supernatant fluid from ultracentrifuged sap.

\section{The dissociation of the inactivating system}

Table 1 showed that the ability to inactivate RTNV was not readily removed from fresh preparations of mitochondria by washing them in large volumes of water. Such an experiment, however, shows only that the washed sediments were still active and not whether any inactivating substances had been removed from them. Table 6 shows that extracts of the sediments do contain inactivating substances and in amounts that are determined by the intervals between the successive centrifugations. In this experiment a 
$10 \mathrm{~g} . / \mathrm{l}$. preparation was sedimented twice from water within one hour of being made. It was re-suspended, left at $0^{\circ}$ for $20 \mathrm{hr}$. and then sedimented again, when it was immediately re-suspended and re-sedimented. The suspension was then left for another 2 days at $0^{\circ}$, when it was again sedimented.

\section{Table 6. Inactivation of $R T N V$ by successive extracts of a mitochondrial preparation}

A $10 \mathrm{~g}$./1. mitochondrial preparation was sedimented 5 times at the intervals specified, and the sediment was each time re-suspended in the original volume of water. Sediments and extracts were kept at $0^{\circ}$ continuously and finally $0.1 \mathrm{ml}$. lots of the extracts were incubated with $20 \mu \mathrm{g}$. of purified virus.

Virus incubated for $20 \mathrm{hr}$. at $18^{\circ}$ with

\section{Water}

1st immediate extract of new preparation 2nd immediate extract of new preparation 3rd extract made after lying $20 \mathrm{hr}$. 4th extract made immediately after 3rd 5th extract made after lying $48 \mathrm{hr}$.

\begin{tabular}{|c|c|}
\hline \multicolumn{2}{|c|}{$\begin{array}{c}\text { Nos. of lesions with } \\
\text { virus at }\end{array}$} \\
\hline $5 \mathrm{mg} . / \mathrm{l}$. & $0.5 \mathrm{mg} . / 1$. \\
\hline 500 & 210 \\
\hline 380 & 137 \\
\hline 500 & 162 \\
\hline 115 & 28 \\
\hline 260 & 86 \\
\hline 380 & 165 \\
\hline
\end{tabular}

Finally the five clear and colourless extracts were tested for their ability to inactivate purified RTNV; the third extract obviously contained much inactivator which was not previously extractable. Most of the inactivating substance was released from the sediment during the first day, but this does not always happen. Equally active extracts have been obtained by sedimenting some preparations on $\mathbf{2}$ or $\mathbf{3}$ successive days.

When $24 \mathrm{hr}$. extracts of sediments are no longer able to inactivate RTNV, the sediments themselves also have little inactivating power (Table 7). The material called 'thrice extracted sediment' in Table 7 is the sediment from the third extract used for the experiment in Table 6, and the ' 9 times extracted sediment' was given four more extractions after being used to provide the fifth extract for the experiment in Table 6 . Table 7 also shows that the inactivating power of a sediment was decreased by the presence of $\mathrm{CHCl}_{3}$ and that the activity of an extract was not destroyed by drying in vacuo.

\section{Table 7. The inactivating power of extracted sediments and dried extract}

Twenty $\mu \mathrm{g}$. purified RTNV were incubated in $0 \cdot 1 \mathrm{ml}$. containing the specified materials and then diluted for testing.

Virus incubated for $20 \mathrm{hr}$. at $18^{\circ}$ with

Water

$1 \mathrm{mg}$. of thrice extracted sediment

$0.2 \mathrm{mg}$. of thrice extracted sediment

$1 \mathrm{mg}$. of thrice extracted sediment with $\mathrm{CHCl}_{3}$

$1 \mathrm{mg}$. of 9 times extracted sediment

$0.1 \mathrm{ml}$. of dried and redissolved extract
Nos. of lesions with virus at

$\begin{array}{cc}5 \mathrm{mg} . / 1 . & 0.5 \mathrm{mg} . / 1 \\ 550 & 140 \\ 2 & 0 \\ 17 & 5 \\ 230 & 60 \\ 530 & 145 \\ 60 & 14\end{array}$


Extracts with virus-inactivating ability can be obtained by extracting sediments at $18^{\circ}$, but less consistently than at $0^{\circ}$. This does not mean that the responsible substance (or substances) is unstable at $18^{\circ}$, for extracts made at $0^{\circ}$ remain active when kept at $18^{\circ}$; they also remain active after boiling briefly and after freezing and thawing. When sediments are enclosed in dialysis tubes and kept at $0^{\circ}$, the virus inactivator occurs in the water surrounding the tubes. Unlike the inactivation by sediments, that by extracts or dialysates occurs when air is excluded or azide is present.

A day or so at $18^{\circ}$, or boiling briefly, destroys the ability of sediments to inactivate RTNV. So also does incubation with $\mathrm{CHCl}_{3}$, which removes the green colour and within a few hours produces a grey-brown coagulum. Thymol seems not to affect the sediment; as virus is also inactivated in its presence, it provides a suitable disinfectant and experiments with it exclude the possibility that the inactivation is caused by bacteria or other microorganisms that grow during the incubation at $18^{\circ}$. Azide, which is also a powerful disinfectant, prevents the sediments from inactivating RTNV but does not destroy the inactivating system, and when the azide is removed the sediments regain their activity. The inhibitory effect of excluding air is also reversible. To identify treatments that specifically affect inactivation by sediments, preparations must be freshly sedimented. If they have lain at $0^{\circ}$ for some hours or days since the last sedimentation, results are equivocal, because the preparations now combine the features of sediments and extracts.

An obvious explanation of the differences between inactivations by mitochondrial preparations and by extracts from them is that the former contain an enzyme system, which makes a substance that diffuses away and inactivates the virus. The system in the mitochondria seems to be readily destroyed and not to function without air or in the presence of azide. The substance is more stable than the system that makes it, and it can inactivate RTNV whether or not air or azide is present.

Active extracts may contain as little as $100 \mathrm{mg}$. dry matter/1., and the main components are breakdown products of nucleic acid, for mitochondrial preparations from all leaves contain both nucleoprotein and ribonuclease, and those from leaves infected with RTNV, like preparations of the virus itself when made by ultracentrifugation, are particularly rich in this enzyme (Pirie, 1957). The enzyme and the nucleoprotein interact slowly, but this process is unlikely to be responsible for producing the virus inactivator, because their interaction is not inhibited by azide (Pirie, 1950) and sediments richest in nucleoprotein are not the most effective inactivators of RTNV.

\section{Analogous inactivations}

As the inactivation of RTNV by extracts from sediments and by citrate (Bawden \& Pirie, 1950b) are similar in some ways and both occur when air is excluded or when azide is present, we tested some other substances that can make complexes with metals. At concentrations around 0.01 $\mathrm{m}$, oxalate did not inactivate, but ethylenediamine tetraacetate at 0.01 and $0.002 \mathrm{M}$ did after some hours at $18^{\circ}$. Hence there is no need to look further for an explanation 
of the inactivation than the sequestration from the virus of some metal that is essential for infectivity and that dissociates only slowly. However, there are other agents, active at biologically significant concentrations, which also inactivate RTNV without denaturing it and whose action is not easily interpreted by the sequestration of some essential metal. Aldehydes, such as formaldehyde and phenylacetaldehyde, at $0.003 \mathrm{M}$ inactivate within a few hours at $18^{\circ}$. Table 8 shows that phenylglyoxal has some effect even at $0.0001 \mathrm{~m}$ and that the effect is not on the host, for adding the substance to inocula immediately before they were rubbed over the leaves did not decrease the numbers of lesions.

\section{Table 8. The inactivation of RTNV by phenylglyoxal}

Samples 1-4 were incubated for $20 \mathrm{hr}$. in air at $18^{\circ}$; each contained $20 \mu \mathrm{g}$. purified RTNV in $0.1 \mathrm{ml}$. and was diluted to $4 \mathrm{ml}$. and tested at this dilution and after further dilution of 1/10. Sample 5 was made like sample 2 but diluted almost immediately, and diluted phenylglyoxal was added to the virus in sample 6 .

\section{Treatment of virus}

1. Incubated with water

2. Incubated with 3 mm-phenylglyoxal

3. Incubated with $1 \mathrm{~mm}$-phenylglyoxal

4. Incubated with $0 \cdot 1$ mu-phenyglyoxal

5. Exposed momentarily to 3 mm-phenylglyoxal and then diluted

6. Diluted phenylgloyxal added immediately before testing
Nos. of lesions after diluting virus to

$\begin{array}{cc}5 \mathrm{mg} \cdot / 1 . & 0.5 \mathrm{mg} \cdot / \mathrm{l} \\ 340 & 100 \\ 21 & 7 \\ 150 & 41 \\ 170 & 78 \\ 250 & 91 \\ 380 & 99\end{array}$

Before we realized that the formation of the virus inactivator from the mitochondrial preparations, and not the final reaction between the inactivator and the virus, was the oxidative process, we made many tests of the effect of oxidizing and reducing systems on the infectivity of RTNV. Although these may not be relevant to inactivation by the extracts of mitochondria, the results with ascorbic acid are interesting enough to warrant recording. We have distinguished three distinct effects. Virus preparations made from leaves that were infiltrated with sodium ascorbate, or from sap to which ascorbate was added at various stages during the processes of isolating the virus, were only one-quarter to one-half as infective as preparations made without this addition. In these experiments, enough $0.1 \mathrm{~m}$ neutralized ascorbic acid was added to sap to increase the concentration to $1 \cdot 0-1 \cdot 5 \mathrm{~g} . / 1$., which is 3-4 times the normal level in tobacco sap. By contrast, ascorbate at these concentrations prevents the inactivation of RTNV contained in mitochondria when these are incubated in the conditions used in the experiments set out in Tables 1 and 2. Cysteine and glutathione also prevent this type of inactivation. After $20 \mathrm{hr}$. at $18^{\circ}$ ascorbic acid or $-\mathrm{SH}$ is still present and the failure of inactivation is presumably a consequence of the maintenance of reducing conditions.

The third effect is the most interesting. Stable preparations of RTNV lose their infectivity when exposed to ascorbate for a day at $18^{\circ}$, and the inacti- 
vation is enhanced instead of inhibited by azide (Table 9). The decreased infectivity produced by exposing the virus briefly to an ascorbate + azide mixture, which had already stood for $20 \mathrm{hr}$., suggests that the responsible substance inactivates the virus rapidly. The substance itself, however, is produced only slowly in the ascorbate + azide mixture, for in tests when the three components were mixed briefly before being diluted and inoculated, the mixtures produced as many lesions as did the control virus solutions. Less than $10 \%$ of the ascorbic acid, as indicated by titration with dichlorophenolindophenol, disappears in $20 \mathrm{hr}$. at $18^{\circ}$. The purified RTNV preparations contain little or no ascorbic oxidase and their inactivation by the ascorbate + azide mixture is lessened by excluding air.

\section{Table 9. The inactivation of RTNV by ascorbic acid and azide}

Ascorbate was used at $0.005 \mathrm{M}$, azide at $0.01 \mathrm{~m}$ and for each treatment $20 \mu \mathrm{g}$. purified RTNV was incubated in $0.1 \mathrm{ml}$. and then was diluted for testing after the stated time.

Virus at $18^{\circ}$ with
Water
Ascorbate for $20 \mathrm{hr}$.
Ascorbate for $2 \mathrm{hr}$.
Ascorbate and azide for $20 \mathrm{hr}$.
Ascorbate and azide for $2 \mathrm{hr}$.
Virus added immediately before testing to a mixture of
ascorbate and azide made $20 \mathrm{hr}$. earlicr

Nos. of lesions with virus at

$\begin{array}{rr}5 \mathrm{mg} . / 1 . & 0.5 \mathrm{mg} . / 1 \\ 650 & 77 \\ 124 & 10 \\ 230 & 23 \\ 4 & 0 \\ 350 & 11 \\ 370 & 6\end{array}$

Lojkin (1937) concluded that a peroxide, made during the catalytic oxidation of ascorbate by a metal, was responsible for the inactivation of tobacco mosaic virus by ascorbic acid, and similar interpretations have been advanced for other oxidations brought about by ascorbic acid (Warren, 1943). If this is the mechanism by which RTNV is inactivated, a peroxide other than $\mathrm{H}_{2} \mathrm{O}_{2}$ is probably responsible, because exposure for $20 \mathrm{hr}$. at $18^{\circ}$ to $0.003 \mathrm{M}-\mathrm{H}_{2} \mathrm{O}_{2}$ affects the infectivity of RTNV only slightly and $0.01 \mathrm{~m}$ is needed for inactivations comparable to those with ascorbate. There are precedents for azide playing a part in peroxide-induced actions (Theorell \& Ehrenberg, 1952; Keilin \& Hartree, 1954), but we have no evidence that such actions are concerned in the inactivation of RTNV.

If any form of oxidation is concerned, it is not easily reversed and, although exposure to reducing agents such as ascorbic acid, cysteine and glutathione stops the inactivation of RTNV by mitochondria, these substances do not restore infectivity to preparations that have lost it. Also, repeated sedimentation of the virus does not restore infectivity after any of the inactivation we have discussed.

\section{Similarities between infective and non-infective virus preparations}

The inactivation by mitochondrial preparations is not accompanied by any gross changes in the serological character or physical state of the virus preparations. Preparations made non-infective still react with virus antiserum 
and give the same precipitin titre and optimal precipitation as when they were infective. Nor does electron microscopy suggest any great change in the particles. Preparations of RTNV contain particles of at least two sizes; the larger particles are more abundant in fresh preparations and the smaller in preparations carried through to the state in which they are less infective and crystallize readily (Bawden \& Pirie, 1945, 1950 a). An obvious explanation would be that the smaller particles are non-infective derivatives of the larger ones. That may explain some types of inactivation. But the inactivations studied here seem not to change large to small particles. The resolving power of our electron microscope is not good enough to identify the particles so precisely that each type can be counted accurately, but preparations made non-infective by sediments, or by extracts from them, still contain large particles and there is nothing to suggest that their proportion has been decreased by inactivation.

The fact that no obvious change accompanies inactivation has two equally plausible explanations. Loss of infectivity may mean a change in only a small part of each virus particle, a change beyond the sensitivity of the methods used. From kinetic studies of the inactivation of tobacco mosaic virus by formaldehyde, Cartwright, Ritchie \& Lauffer (1956) concluded that inactivation could result from the reaction of one formaldehyde molecule at one site on a virus particle, perhaps with a hydroxy group on ribose. Such a reaction would not be expected to affect either morphology or serological activity. Alternatively, most of the particles in even the most active preparations may already be non-infective, so that changes in affected particles could be considerable but would occur in too small a fraction of the whole to be detected.

\section{DISCUSSION}

Our results adequately explain the variations in infectivity between preparations of RTNV made from sap by different methods, and this point calls for no more discussion. There are, though, other phenomena less readily explained. When the virus is extracted from the residue that remains after leaves are minced and their sap expressed, it is, weight for weight, less infective than virus got from the sap (Bawden \& Pirie, 1950a). We have confirmed this with many different batches of leaves, and have now further found that the infectivity is greater when supernatant fluid from ultracentrifuged sap is used to extract the virus from the leaf residue than when water is used. These different extracting fluids could act by influencing the extent to which the virus inactivator operates during the course of extraction. While sap is present it seems to be inactive, but when the sap is removed it may come into operation. This simple explanation is not fully adequate, however, because extracts made with sodium azide solution, which prevents mitochondrial inactivation of RTNV in vitro, yield virus that is no more infective than virus extracted with water.

Another phenomenon for which there is no adequate explanation is the low infectivity of virus made from the sap of leaves frozen before being minced. 
In 1950 we explained this as a failure of an activating mechanism which we then postulated. RTNV does not lose infectivity when minced leaves or sap are frozen and there is not always a loss when intact leaves are frozen. It is more evident when leaves that have been infected for many days and are very chlorotic are frozen at -5 to $-10^{\circ}$, than when young leaves are used, or when leaves are frozen quickly at $-\mathbf{2 0 ^ { \circ }}$. Neither the inactivation that follows freezing nor that in residues of minced leaves need be correlated with the inactivating system we have described, but they could result from changes in the microanatomy of the leaf that alter the relative disposition of virus particles and the mitochondria.

As extracts from plants infected by viruses are studied in greater detail it becomes increasingly evident that they contain a range of anomalous particles not all of which are infective. Some lack nucleic acid; but some that contain nucleic acid are also not infective. It does not seem that the virus-inactivating system we have described plays any part in producing the non-infective nucleoprotein that is serologically related to tobacco mosaic virus (Bawden \& Pirie, 1945, 1956), for when preparations of this virus were incubated with mitochondrial sediments their infectivity was unimpaired. However, with RTNV, tobacco ringspot and other viruses that lose their infectivity more readily than does tobacco mosaic, it could play a part in producing such components, particularly in preparations made by ultracentrifugation. There is at the moment no way of telling whether the system operates at all in vivo, though the assumption that it does provides a ready explanation for the fact that preparations of RTNV made from different lots of leaves by a method designed to preserve infectivity in vitro can still differ considerably in their relative infectivities. There seems, too, a suggestion of biological significance in the fact that the inactivating system is more evident in leaves infected with viruses affected by the system than in healthy leaves or those infected with tobacco mosaic virus, but work with many more viruses will be needed before this becomes more than a suggestion.

We thank Mr R. H. Kenten for making the measurements of catalase and oxygen uptake, Mr H. L. Nixon for making the electromicrographs, and the Distillers Co. for a gift of glutathione.

\section{REFERENCES}

Bawden, F. C. \& Pirie, N. W. (1945). Further studies on the purification and properties of a virus causing tobacco necrosis. Brit. J. exp. Path. 26, 277.

Bawden, F. C. \& Pirie, N. W. (1950 $a$ ). Some factors affecting the activation of virus preparations made from tobacco leaves infected with a tobacco necrosis virus. J. gen. Microbiol. 4, 464 .

Bawden, F. C. \& Prrie, N. W. (1950b). Some effects of freezing in the leaf, and of citrate in vitro, on the infectivity of a tobacco necrosis virus. J. gen. Microbiol. 4,482 .

Bawden, F. C. \& Pirie, N. W. (1956). Observations on the anomalous proteins occurring in extracts from plants infected with strains of tobacco mosaic virus. J. gen. Microbiol. 14, 460. 
Cartwright, T. E., Ritchie, A. E. \& Lauffer, M. A. (1956). The reaction of tobacco mosaic virus with formaldehyde. III. Kinetics of the loss of infectivity. Virology, 2, 689.

Keilin, D. \& HARTree, E. F. (1954). Reactions of methaemoglobin and catalase with peroxides and hydrogen donors. Nature, Lond. 173, 720.

LoJkin, M. (1937). A study of ascorbic acid as an inactivating agent of tobacco mosaic virus. Contr. Boyce Thompson Inst. 8, 445.

Pirie, N. W. (1950). The isolation from normal tobacco leaves of nucleoprotein with some similarity to plant viruses. Biochem. J. 47, 614 .

Pirie, N. W. (1953). Some host components that affect viruses during isolation. In Interaction of Virus and Cells, Symp. 6th. Congr. int. Microbiol., p. 11.

Pirie, N. W. (1956). A disintegrator for use with small quantities of fresh leaves. J. Agric. engng Res. $1,8$.

Pirie, N. W. (1957). Macromolecular nucleoproteins from healthy tobacco leaves. Biochimia (in the Press).

Steere, R. L. (1956). Purification and properties of tobacco ringspot virus. Phytopathology, 46, 60.

Theoreli, H. \& Ehrenberg, A. (1952). The reaction between catalase, azide and hydrogen peroxide. Arch. Biochem. Biophys. 41, 462.

WARREN, F. L. (1943). Aerobic oxidation of aromatic hydrocarbons in the presence of ascorbic acid. Biochem. J. 37, 338.

(Received 28 December 1956) 